\title{
Contribution of Animal Agriculture to Greenhouse Gases Production in Swaziland
}

\author{
A. M. Dlamini' ${ }^{1}$ M. A. Dube ${ }^{2}$ \\ ${ }^{1}$ Department of Animal Science, University of Swaziland, Private Bag Luyengo, Swaziland \\ ${ }^{2}$ Department of Agricultural Education and Extension, University of Swaziland, Private Bag Luyengo, Swaziland \\ Email: adlamini@uniswa.sz, madube@uniswa.sz
}

Received 22 June 2014; revised 18 July 2014; accepted 7 August 2014

Copyright (C) 2014 by authors and Scientific Research Publishing Inc.

This work is licensed under the Creative Commons Attribution International License (CC BY). http://creativecommons.org/licenses/by/4.0/

(c) (7) Open Access

\section{Abstract}

The economy of Swaziland is depended on agriculture. In 2009, it was reported that agriculture, forestry, and manufacturing contributed $42 \%$ of Swaziland's Gross Domestic Product (GDP). Besides economic importance, animal agriculture is important for food production and life sustenance. It is also viewed as a symbol of wealth and high social status particularly for the rural folks. Despite the merits of agricultural activities, agricultural production, particularly animal production, has been incriminated for an accelerated emission of greenhouse gases. These gases are responsible for global warming and climate change. The aim of this study was to determine the contribution of animal agriculture to greenhouse gases production and to elicit adaptation strategies to climate change and the role of modern technologies as mitigating measures. The minor and major greenhouse gases produced by farm animals were computed using the IPCC spread sheet for calculation of greenhouse gases emissions. The minor greenhouse gases produced by farm animals were $\mathrm{NO}_{\mathrm{x}}$ and $\mathrm{CO}_{2}$ and the major gasses included $\mathrm{CH}_{4}$ and $\mathrm{N}_{2} \mathrm{O}$. The greenhouse gas that was emitted the most by farm animals was $\mathrm{CH}_{4}, 24 \mathrm{Gg}$ or $600 \mathrm{CO}_{2} \mathrm{e}$ per annum. Ruminants were the major producers of methane. The producers of the least greenhouse gases emissions were non ruminants. Livestock produced $0.87 \mathrm{Gg}$ of $\mathrm{N}_{2} \mathrm{O}$ per annum, a global warming potential of $259 \mathrm{CO}_{2} \mathrm{e}$. Feeding ammoniated straw and silage inoculating with transgenic rumen bacteria, animal breeding and manure storage techniques, use of biogas digester with methane gas recovery and emphasis on non ruminant production were possible strategies that could be employed to reduce greenhouse gases production from the livestock sector. It was recommended that feed preservation technologies, selection strategies, water harvesting, storage and recycling strategies and intensive livestock production systems could be used as adaptation strategies to climate change in livestock production. 


\section{Keywords}

\section{Greenhouse Gases, Animal Agriculture, Methane, Global Warming, Climate Change, Adaptation}

\section{Introduction}

Swaziland is located in south eastern Africa, sandwiched between Mozambique on the eastern part and South Africa on the other parts covering an area of about $17,400 \mathrm{~km}^{2}$. Like many countries in the developing world, the economy of Swaziland is depended on agriculture. In 2009, the gross domestic product (GDP) of Swaziland was estimated at US \$3.59 billion and a gross per capita income of US \$3108 (2008 estimates). The annual growth rate for the country has ranged from $2.0 \%$ in 2000 to $3.9 \%$ in 2003 and $1.2 \%$ in 2009. The estimate for 2011 is $0.5 \%$ [1]. In 2009, the contribution of agriculture to the GDP was $8.4 \%$ and this has decreased from $13 \%$ in 1989. Manufacturing's contribution has been relatively higher, about $42.4 \%$ in 2009. However, it should be noted that about $70 \%$ of the manufacturing industry is agro-based, indicating that the contribution by the agricultural sector could be much higher than $8.4 \%$ [2].

Agriculture plays a great role in income generation particularly for the rural community, in provision of raw materials for the manufacturing industries, and in generation of export products for foreign exchange. The major export products are: Sugar, wood pulp, citrus fruits, beef, live animals, textiles, soft drink concentrates and coal [3]. About 127,842 ha are used for crop production. Sugar cane and maize occupy the largest proportion of arable land, 45,000 and 71,973 ha, respectively [4]. Grazing lands occupied about $60 \%$ of the whole country, mainly on communally owned ranches known as Swazi Nation Land (SNL) [4]. Cultivated pastures used mainly for dairy production, covers $5 \%$ of available grazing land. Cultivated forestry covers about $6 \%$ of the total land area. The major agricultural income earners in Millions Local Currency (SDEm) of the country in 2004 were sugar 644.8, wood pulp 443.7, citrus and pineapple 159.2, meat 19.1 and cotton 12.5 [3]. In overall, animal production contributes about 1\% of the country's GDP and the major animal species raised in Swaziland are cattle, goats, sheep, pigs, equines and poultry. Agriculture in the SNL is mostly subsistence, despite that the Ministry of Agriculture [5] has developed strategies as a result of the Agricultural Summit of 2007, for farmers to graduate from subsistence to commercial farming.

Although the contribution of animal agriculture to economic development is significant, its contribution to climate change cannot be overlooked. Climate change is one problem that dominates media headlines in recent memory [6]. The current global warming trend of the atmosphere has been among scientists, politicians, and individuals around the world a cause for great concern. Dramatic reductions in seasonal sea ice at the Earth's poles, rising sea-level, shifts in precipitation patterns leading to extended droughts or flooding, and more frequent extreme weather events are just some of the effects of global warming and changes to the global climate change [6]. All countries, developed or underdeveloped, are affected, thus making it clear that climate change mitigation and adaptation are necessary to address one of the greatest challenges faced by the world today.

Climate change is a complex global problem because it is intertwined with many other issues such as economic development and poverty reduction. Developing countries like Swaziland are the least responsible for climate change. Yet, they are the most at risk from its effects [7] [8]. The predicament faced by most developing countries is that, eradicating poverty and improving living conditions via the attainment of the Millennium Development Goals (MDGs), must remain a priority [6]. The challenge here is to accomplish the MDGs while reducing dependence on carbon, promoting climate resilience and ensuring balanced economic development [6].

In 1992, international concern about global warming was translated into the United Nations Framework Convention on Climate Change (UNFCCC). This global treaty encouraged action to stabilize greenhouse gas emissions. In 1997, this "encouragement" was strengthened into a "commitment" for action via the Kyoto Protocol. In 2005, the Kyoto Protocol entered into force, thus committing the developed country signatories to reduce their emissions of greenhouse gases following the rules outlined in the Marrakech Accords of 2001. Following the 1992 UN treaty, countries were encouraged to compute and communicate their greenhouse gases emissions.

The purpose of this study was to determine trends in greenhouse gas emissions in the animal agriculture sector in Swaziland and identify implications for adaptation and mitigation strategies. The specific objectives of the study were to:

1) Determine amounts of greenhouse gases produced by the animal production sector in Swaziland;

2) Determine trends in greenhouse gases production by the animal agriculture sector from 2000 to 2010; 
3) Identify adaptation and mitigation strategies that can be used to minimize greenhouse gas emissions from animal agriculture.

\section{Methodology}

\subsection{Greenhouse Gas Emissions}

The emissions considered were: $\mathrm{CH}_{4}$ emissions from domesticated animals enteric fermentation and solid waste; $\mathrm{N}_{2} \mathrm{O}$ emissions from animal waste and pastures. Minor GHG produced during veld burning.

\subsection{Mitigation Strategies}

Desktop research was conducted to identify possible mitigation strategies that could be used to reduce emission of greenhouse gases from animal production activities.

\subsection{Source of Data}

Livestock production data were obtained from the Livestock Census Unit, Ministry of Agriculture (MOA) and Swaziland Dairy Board (SDB). Crop production data were sourced from Swaziland Census of Agriculture and Central Statistical Office. Data were also sourced from the Chinese Agricultural Technical Mission, Swaziland Fruit Canners, Swaziland Sugar Association. Burning of savanna data were sourced from Swaziland National Trust Commission, and the Department of Agriculture and Extension Services, MOA.

\subsection{Data Processing}

The greenhouse gas emissions were calculated using the IPCC spreadsheet for calculation of greenhouse gasses emission [9]. Calculations were done using default values and equations from the IPCC 1996 reference manual tier 1 approach.

\subsection{Greenhouse Gas Emissions}

The emissions considered were calculated as follows:

Equation (1) was used to calculate methane $\left(\mathrm{CH}_{4}\right)$ production from enteric fermentation from domesticated animals and solid waste

$$
\mathrm{CH}_{4} \text { emission }(\mathrm{Gg}) / \mathrm{yr}=\text { Emission factor }(\mathrm{kg} / \mathrm{head} / \mathrm{yr}) \times \text { Livestock population } /\left(10^{6} \mathrm{~kg} / \mathrm{Gg}\right)
$$

Equation (2) was used to calculate Nitrous oxide production from animal waste management systems:

$$
\mathrm{N}_{2} \mathrm{O}_{\text {animals }}=\mathrm{N}_{2} \mathrm{O}_{(\mathrm{AWMS})}=\Sigma\left[\mathrm{N}_{(\mathrm{T})} \times \mathrm{Nex}_{(\mathrm{T})} \times \mathrm{AWMS}_{(\mathrm{T})} \times \mathrm{EF}_{3(\mathrm{AWMS})}\right]
$$

With:

$\mathrm{N}_{2} \mathrm{O}_{\text {animals }}=\mathrm{N}_{2} \mathrm{O}$ emissions from animal production in the country (Gg);

$\mathrm{N}_{2} \mathrm{O}_{\text {(AwMS) }}=\mathrm{N}_{2} \mathrm{O}$ emissions from animal waste management systems in the country (kg N/yr);

$\mathrm{N}_{(\mathrm{T})}=$ Number of animals of type $\mathrm{T}$ in the country;

$\operatorname{Nex}_{(\mathrm{T})}=\mathrm{N}$ excretion of animals of type $\mathrm{T}$ in the country (kg N/animal/yr);

$\mathrm{AWMS}_{(\mathrm{T})}=$ Fraction of $\operatorname{Nex}_{(\mathrm{T})}$ that is managed in one of the different distinguished animal waste management systems for animals of type $\mathrm{T}$ in the country;

$\mathrm{EF}_{3(\mathrm{AWms})}=\mathrm{N}_{2} \mathrm{O}$ emission factor for AWMS ( $\mathrm{kg} \mathrm{N}_{2} \mathrm{O}-\mathrm{N} / \mathrm{kg}$ of Nex in AWMS).

Equation (3) was used to calculate direct $\mathrm{N}_{2} \mathrm{O}$ emission from agricultural production.

$$
\mathrm{N}_{2} \mathrm{O}_{\text {Direct }}=\left[\left(\mathrm{F}_{\mathrm{SN}}+\mathrm{F}_{\mathrm{AW}}+\mathrm{F}_{\mathrm{BN}}+\mathrm{F}_{\mathrm{CR}}\right) \times \mathrm{EF}_{1}\right]+\mathrm{F}_{\mathrm{OS}} \times \mathrm{EF}_{2}
$$

With:

$\mathrm{N}_{2} \mathrm{O}_{\text {Direct }}=$ direct $\mathrm{N}_{2} \mathrm{O}$ emissions from agricultural soils in the country (Gg); 
$\mathrm{EF}_{1}=$ emission factor for direct soil emissions $\left(\mathrm{kg} \mathrm{N}_{2} \mathrm{O} / \mathrm{kg} \mathrm{N}\right.$ input$) ;$

$\mathrm{EF}_{2}=$ emission factor for organic soils mineralization due to cultivation ( $\mathrm{kg} \mathrm{N}_{2} \mathrm{O} \mathrm{N}$ ha/yr);

$\mathrm{F}_{\mathrm{OS}}=$ area of cultivated organic soils within the country (ha histosols);

$\mathrm{F}_{\mathrm{AW}}=$ manure nitrogen used as fertilizer in the country, corrected for $\mathrm{NH}_{3}$ production and $\mathrm{NO}_{\mathrm{x}}$ emissions, excluding manure produced during grazing $(\mathrm{kg} \cdot \mathrm{N} / \mathrm{yr})$;

$\mathrm{F}_{\mathrm{BN}}=\mathrm{N}$ fixed by $\mathrm{N}$ fixing crops in the country $(\mathrm{kg} \cdot \mathrm{N} / \mathrm{yr})$;

$\mathrm{F}_{\mathrm{CR}}=\mathrm{N}$ in crop residues returned to soils in the country ( $\mathrm{kg} \mathrm{N} / \mathrm{yr}$ );

$\mathrm{F}_{\mathrm{SN}}=$ Synthetic $\mathrm{N}$ applied in the country (kg N/yr).

Equation (4) was used to calculate $\mathrm{N}_{2} \mathrm{O}$ emissions from indirect agricultural soils cultivation.

$$
\mathrm{N}_{2} \mathrm{O}_{\text {indirect }}=\mathrm{N}_{2} \mathrm{O}_{(\mathrm{G})}+\mathrm{N}_{2} \mathrm{O}_{(\mathrm{L})}
$$

With:

$\mathrm{N}_{2} \mathrm{O}_{\text {indirect }}=$ Indirect nitrous oxide emission from the soil in the country (Gg);

$\mathrm{N}_{2} \mathrm{O}_{(\mathrm{G})}=\mathrm{N}_{2} \mathrm{O}$ produced from atmospheric deposition of $\mathrm{NO}_{\mathrm{x}}$ and $\mathrm{NH}_{3}(\mathrm{~kg} \mathrm{~N} / \mathrm{yr})$;

$\mathrm{N}_{2} \mathrm{O}_{(\mathrm{L})}=\mathrm{N}_{2} \mathrm{O}$ produced from $\mathrm{N}$ leaching and runoff ( $\left.\mathrm{kg} \mathrm{N} / \mathrm{yr}\right)$.

\section{Results and Discussion}

As stated above, the overall contribution of animal production to the economy was about $1 \%$ of the country's GDP and the major animal species raised in Swaziland are cattle, goats, sheep, pigs, equines and poultry [10]. As can be seen from Figure 1, there has been a gradual increase in goat production from about 270,000 in 1985/86 to about 480,000 in 2009/10, whereas there has been no marked increases in cattle production over the same period.

Poultry as presented in Figure 2, are the most popular farm animals, reaching 2,000,000 in 2010. Results have also shown that during the past decade, there were significant increases in population of pigs, sheep and equids in Swaziland (Figure 3).

The major greenhouse gases emitted from agricultural production are $\mathrm{CH}_{4}$ and $\mathrm{N}_{2} \mathrm{O}$ whereas $\mathrm{CO}$ and $\mathrm{NO}_{\mathrm{x}}$ are considered the minor greenhouse gases produced by agricultural activities [7] [8]. The main agricultural activities that are responsible for greenhouse gas production are: enteric fermentation, veld burning, biomass decomposition, manure storage and disposal, cultivation of agriculture fields, burning of crop residues and use of fertilizers.

The second national communication report for Swaziland to the UNFCCC [11] has shown that agriculture contributes about $8 \%$ of the total greenhouse emissions in the country. The greenhouse gas emissions produced by agricultural activities in the country are presented in Table 1 . The results have also shown that the major livestock greenhouse gas is $\mathrm{CH}_{4}$ and that livestock production contributed about $45 \%$ of the agriculture greenhouse gas emission through enteric fermentation, manure storage and rangelands veld fires (Figure 4).

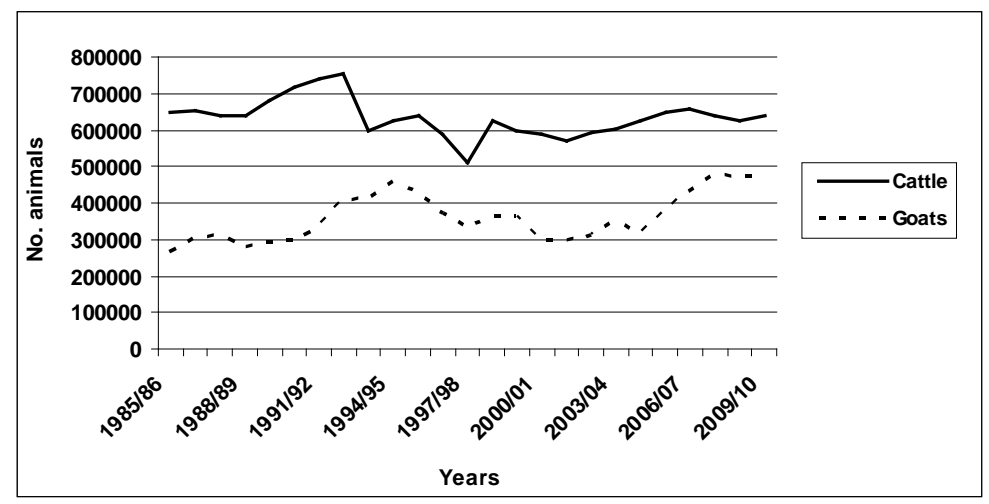

Figure 1. Cattle and goat production in Swaziland in 1985 to 2010. 


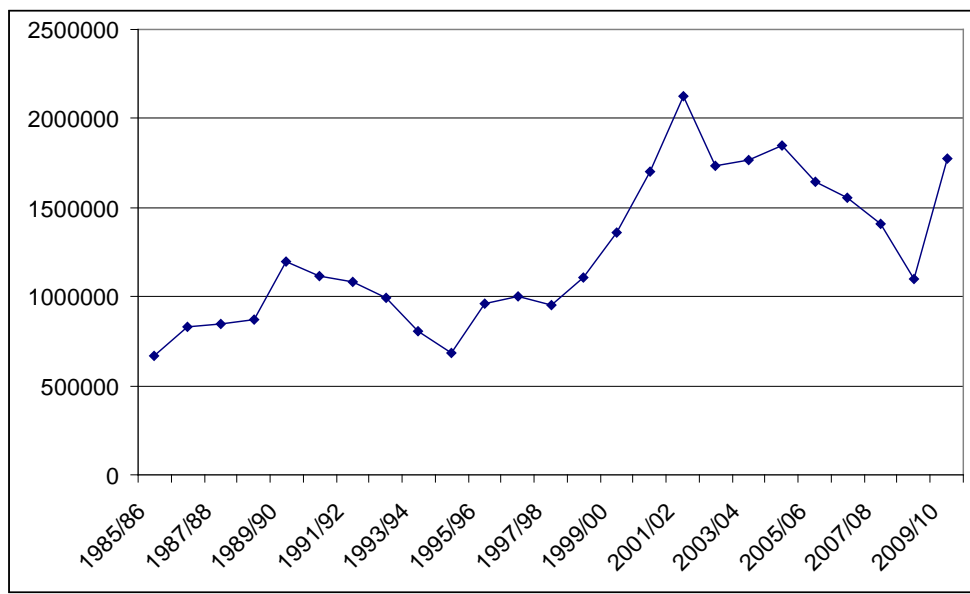

Figure 2. Poultry population from 1985 to 2010.

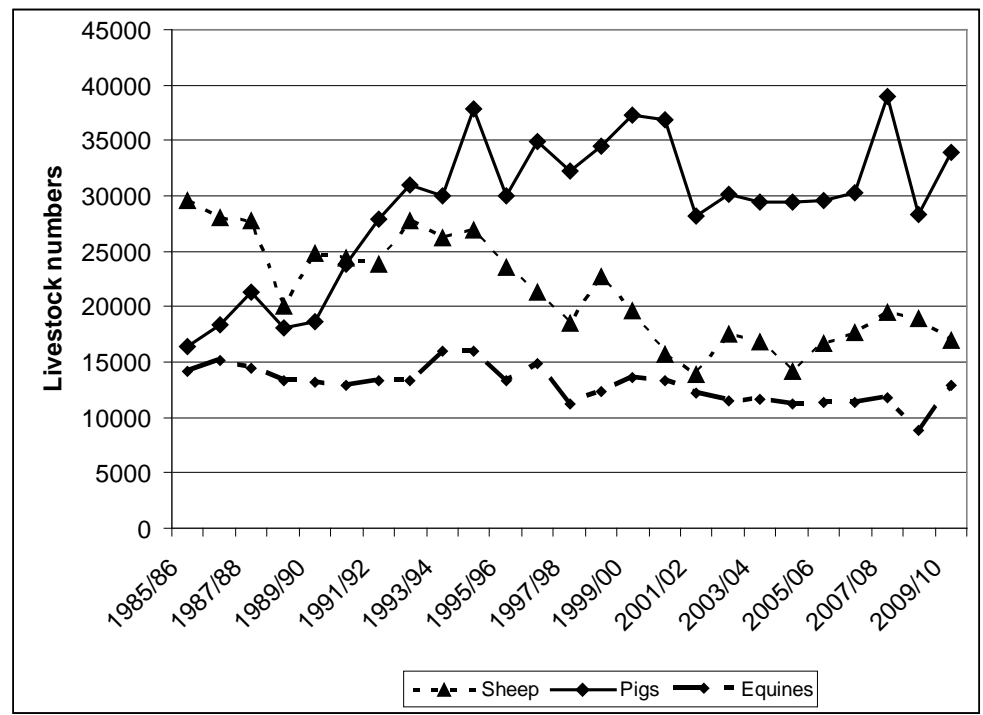

Figure 3. Sheep, pigs and equine populations in Swaziland from 1985 to 2010.

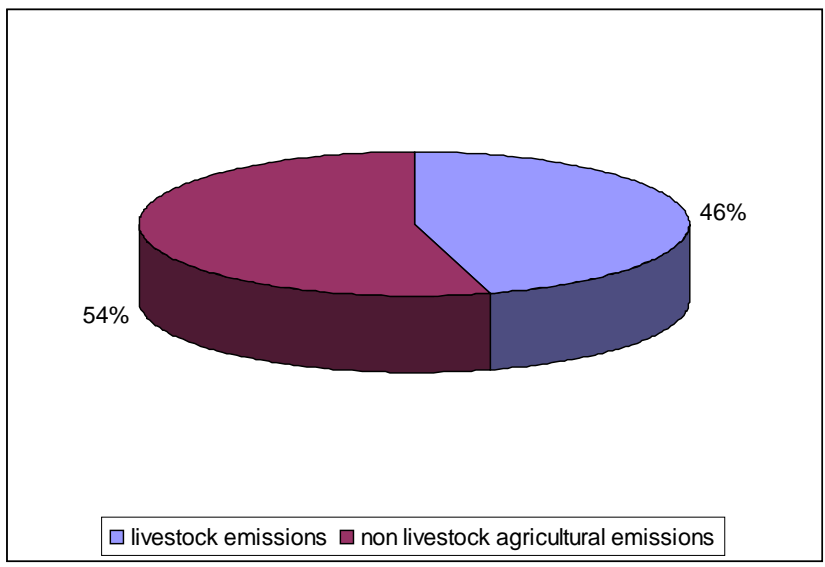

Figure 4. Contribution of livestock production to total agricultural greenhouse gases emissions. 
Table 1. Production of major greenhouse gases from agricultural activities in Swaziland in 2000 [11].

\begin{tabular}{ccccc}
\hline $\begin{array}{c}\text { Greenhouse Gas Source and Sink } \\
\text { Categories }\end{array}$ & $\begin{array}{c}\mathrm{CH}_{4} \\
\left(\mathrm{CO}_{2} \text { Equivalent } \mathrm{Gg}\right)\end{array}$ & $\begin{array}{c}\mathrm{N}_{2} \mathrm{O} \\
\left(\mathrm{CO}_{2} \text { Equivalent Gg) }\right.\end{array}$ & $\begin{array}{c}\text { Total } \\
\left(\mathrm{CO}_{2} \text { Equivalent } \mathrm{Gg}\right)\end{array}$ & $\begin{array}{c}\text { \% of Agriculture } \\
\text { Contribution }\end{array}$ \\
\hline $\begin{array}{c}\text { A. Enteric Fermentation } \\
\text { B. Manure Management }\end{array}$ & 434.55 & - & 434.55 & 27.2 \\
C. Rice Cultivation & 15.41 & - & 15.41 & 1.0 \\
D. Agricultural Soils & 0.0084 & - & 0.0084 & 0 \\
E. Prescribed Burning of Savannas & 232.47 & 629.3 & 629.3 & 39.3 \\
F. Field Burning of Agricultural & 166.97 & 43.4 & 275.87 & 17.3 \\
$\quad$ Residues & 849.41 & 80.8 & 247.77 & 15.5 \\
Total Agriculture & & 753.5 & 1602.91 & 100 \\
\hline
\end{tabular}

Table 2. Trends in greenhouse gas emissions by livestock in Swaziland from 2000 to 2010.

\begin{tabular}{cccc}
\hline Year & $\begin{array}{c}\mathrm{CH}_{4} \text { Production } \\
\left(\mathrm{CO}_{2} \text { Equivalent } \mathrm{Gg}\right)\end{array}$ & $\begin{array}{c}\mathrm{N}_{2} \mathrm{O} \text { Production } \\
\left(\mathrm{CO}_{2} \text { Equivalent } \mathrm{Gg}\right)\end{array}$ & $\begin{array}{c}\text { Total } \\
\left(\mathrm{CO}_{2} \text { Equivalent Gg) }\right.\end{array}$ \\
\hline 2000 & 535.8 & 235.4 & 771.2 \\
2001 & 521.3 & 229.5 & 750.8 \\
2002 & 545 & 238.4 & 783.4 \\
2003 & 555.3 & 242.4 & 796.7 \\
2004 & 554 & 238.4 & 792.4 \\
2005 & 569.5 & 250.3 & 819.8 \\
2006 & 579 & 256.3 & 835.3 \\
2007 & 611.8 & 259.3 & 871.1 \\
2008 & 603.5 & 256.3 & 859.8 \\
2009 & 589.3 & 247.4 & 836.6 \\
\hline
\end{tabular}

Results from the present study have shown that the major greenhouse gasses emitted by livestock production in Swaziland were: $\mathrm{CH}_{4}$ from enteric fermentation, manure management and burning of rangelands; $\mathrm{NO}_{2}$ from manure management and burning of rangelands. Methane is produced by domestic animals during digestion of carbohydrates by microorganisms in the alimentary tract of herbivores. The results presented in Table 2 shows that the amount of $\mathrm{CH}_{4}$ produced by livestock activities during the past decade increased from about $530\left(\mathrm{CO}_{2}\right.$ Equivalent $\mathrm{Gg})$ in 2000 to $600\left(\mathrm{CO}_{2}\right.$ Equivalent $\left.\mathrm{Gg}\right)$ in 2010. $\mathrm{N}_{2} \mathrm{O}$ emissions increased slightly from about 230 ( $\mathrm{CO}_{2}$ Equivalent $\left.\mathrm{Gg}\right)$ to about $250\left(\mathrm{CO}_{2}\right.$ Equivalent $\left.\mathrm{Gg}\right)$.

The results in Table 2 have also shown that greenhouse gases emissions were generally increasing in the last decade. Methane production depends upon the digestive system of the animal and feed intake. Ruminant animals, cattle, sheep, goats, have the highest emission, followed by pseudo-ruminants, donkeys, mules and horses, and non ruminants, poultry and pigs, have the least emissions. Animals with a higher feed intake, for example, cattle, generally have higher methane emission than smaller animals with a lower feed intake.

In Swaziland, the livestock rearing system for ruminants and pseudo ruminants involve raising the animals in the pasture or rangeland during the day and keeping them in the kraal at knight, commonly known as night kraaling. The manure accumulates in the kraal until it is time to spread it in the crop fields. Some of the remaining manure is spread in the pastures. During the period when the heaps of the manure are kept, greenhouse gases are emitted to the atmosphere. The non-ruminants are raised in doors and their waste is also disposed-off as dry solid waste in the pastures or crop fields. This means that the animal waste management systems used are solid 
storage, dry lots and pasture manure.

The contribution of livestock production to the agriculture greenhouse gas emissions is about $46 \%$. The population of the country is rising, thus increasing the demand for food, fuel, fibre, and agricultural processed products and this figure is likely to rise. New technologies and agricultural practices for livestock management may contribute to mitigation of greenhouse gases production while improving productivity. Smith et al. [12] described two major technologies that can help mitigate greenhouse gas emissions and promote a sustainable livestock production system. These related major techniques include:

\subsection{Reduction of $\mathrm{CH}_{4}$ by Ruminants}

Ruminant production is the major producer of $\mathrm{CH}_{4}$ in agriculture. Inoculating silage fermenting bacteria with genetically engineered culture that will reduce $\mathrm{CH}_{4}$ production in the rumen is a promising biotechnology strategy that may result in significant $\mathrm{CH}_{4}$ emission reductions. The adoption of a biotechnological strategy may not present serious problems as previous reports have shown that there is a general acceptance and tolerance of the technology by the people of the country [13]. Other possible strategies that may be used to reduce methane production include foliar application of liquid $\mathrm{N}$ fertilisers $\left(\left(\mathrm{NH}_{4}\right)_{2} \mathrm{SO}_{4}\right)$ in pasture fields. This was found to decrease $\mathrm{CH}_{4}$ emissions by $5 \%$ - 25\% [14].

\subsection{Manure/Bio-Solid Management (Biogas)}

This involves improving systems for storage and handling of manure. Under our local conditions, the manure is kept in the kraal and later spread in the field. This result in releases of $\mathrm{N}_{2} \mathrm{O}$ and $\mathrm{CH}_{4}$ direct into the atmosphere. A biotechnology strategy that can be employed could be use of anaerobic fermentation of livestock waste (anaerobic digestion) systems such as use of biogas digester with methane recovery. This system could be used in intensive ruminant production systems such as commercial dairy farms and feedlots. The advantage of the system is that besides reducing GHG emission, the farmer also benefits from capturing the biogas.

\subsection{Climate Change Adaptation Strategies}

Greenhouse gases production results in climate change. According to Government of Swaziland [15] [16], the projected scenarios of the impact of climate change in Swaziland are less water and higher temperatures. This implies that more efficient use of water for pasture and livestock rearing and radical changes in livestock farming practices must promote conservation of water and heat tolerance. Adaptation strategies must promote fodder conservation and its efficient consumption. Climate change will also promote proliferation of pests and diseases thus decreasing livestock productivity [15] [16]. It is expected that the range of many insects will expand or change, and new combinations of pests and diseases may emerge as natural ecosystems respond to altered temperature and precipitation [16] [17]. Increase in the frequency or severity of extreme weather events, including droughts, heat waves, windstorms, or floods, could also disrupt the predator-prey relationships that normally keep pest populations in check. It is thus recommended that feed preservation technologies, selection strategies, water harvesting, storage and recycling strategies and intensive livestock production systems could be used as adaptation strategies to climate change during livestock production.

\section{Conclusion}

It can be concluded that although animal agriculture is important for food production and economic development, its contribution to greenhouse gases emissions is significant. Biotechnology may be used to mitigate greenhouse gas emissions from manure and enteric fermentation. Possible technologies include use of anaerobic fermentation to produce biogas and inoculating genetically engineered rumen bacteria to reduce methane production by the ruminant.

\section{References}

[1] Global Finance (2011) Swaziland GDP Data and Country Report. http://www.gfinag.com/gdp-data-country-report/170-swaziland-gdp-com

[2] Central Bank of Swaziland (2012) Annual Report: April 2011-March 2012. Office of Governor, Mbabane.

[3] SADC (2005) Official SADC Trade Industry and Investment Review. Southern African Marketing Company (Pty) Ltd., 
Gaborone, 219-231.

[4] Swaziland Government (2011) Annual Statistical Bulletin. Central Statistics Office, Mbabane.

[5] Swaziland Government (2008.) National Agricultural Summit Projects and Programmes. Ministry of Agriculture, Mbabane.

[6] UNDP (1998) Climate Change and the Millennium Development Goals. http://www.undp.org/climatechange/cc_mdgs.shtml

[7] IPCC (2000) Special Report on Emissions Scenarios. Cambridge University Press, Cambridge.

[8] IPCC (2007) Climate Change 2007: Impacts, Adaptation and Vulnerability. Cambridge University Press, Cambridge.

[9] IPCC (1996) Guidelines for National Greenhouse Gas Inventory. IPCC WGI Technical Support Unit, London, Chapter 4.

[10] Swaziland Government (2011) Livestock Census. Ministry of Agriculture, Mbabane.

[11] Swaziland Government (2012) Second National Communication to the United Nation Framework Convention on Climate Change. Swaziland Meteorological Services, Mbabane.

[12] Smith, P., Martino, D., Cai, Z., Gwary, D., Janzen, H.H., Kumar, P., Mccarl, B., Ogle, S., O’mara, F., Rice, C., Scholes, R.J., Sirotenko, O., Howden, M., Mcallister, T., Pan, G., Romanenkov, V., Schneider, U., Towprayoon, S., Wattenbach, M. and Smith, J.U. (2008) Greenhouse Gas Mitigation in Agriculture. Philosophical Transactions of the Royal Society B: Biological Sciences, 363, 789-813. http://dx.doi.org/10.1098/rstb.2007.2184

[13] Dlamini, A.M., Dube, M.A. and Nkambule, N. (2008) Stakeholders’ Perceptions and Application of Biotechnology in the Agricultural Industries in Swaziland. Scientific Research and Essays, 3, 477-487.

[14] Kimura, M., Asai, K., Watanabe, A., Murase, J. and Kuwatsuka, S. (1992) Suppression of Methane Fluxes from Flooded Paddy Soil with Rice Plants by Foliar Spray of Nitrogen Fertilisers. Soil Science and Plant Nutrition, 38, 735-740. http://dx.doi.org/10.1080/00380768.1992.10416704

[15] Government of Swaziland (2013) Draft Report of the National Strategy for Climatic Change. Ministry of Tourism and Environmental Affairs, Mbabane.

[16] Blanc, E. (2012) The Impact of Climate Change on Crop Yields in Sub-Saharan Africa. American Journal of Climate Change, 1, 1-13. http://dx.doi.org/10.4236/ajcc.2012.11001

[17] Jarvis, A., Upadhyaya, H., Gowda, C.L.L., Aggarwal, P.K., Fujisaka, S. and Anderson, B. (2011) Climate Change and Its Effect on Conservation and Use of Plant Genetic Resources for Food and Agriculture and Associated Biodiversity for Food Security. FAO, Rome. 
Scientific Research Publishing (SCIRP) is one of the largest Open Access journal publishers. It is currently publishing more than 200 open access, online, peer-reviewed journals covering a wide range of academic disciplines. SCIRP serves the worldwide academic communities and contributes to the progress and application of science with its publication.

Other selected journals from SCIRP are listed as below. Submit your manuscript to us via either submit@scirp.org or Online Submission Portal.
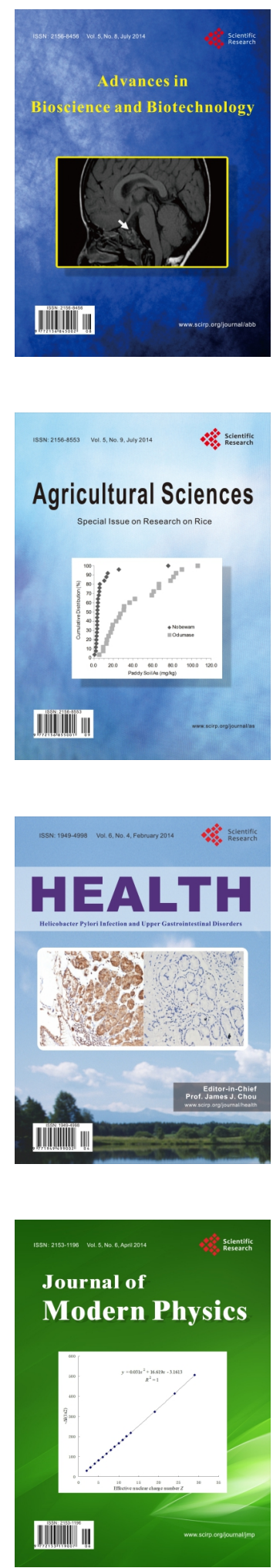
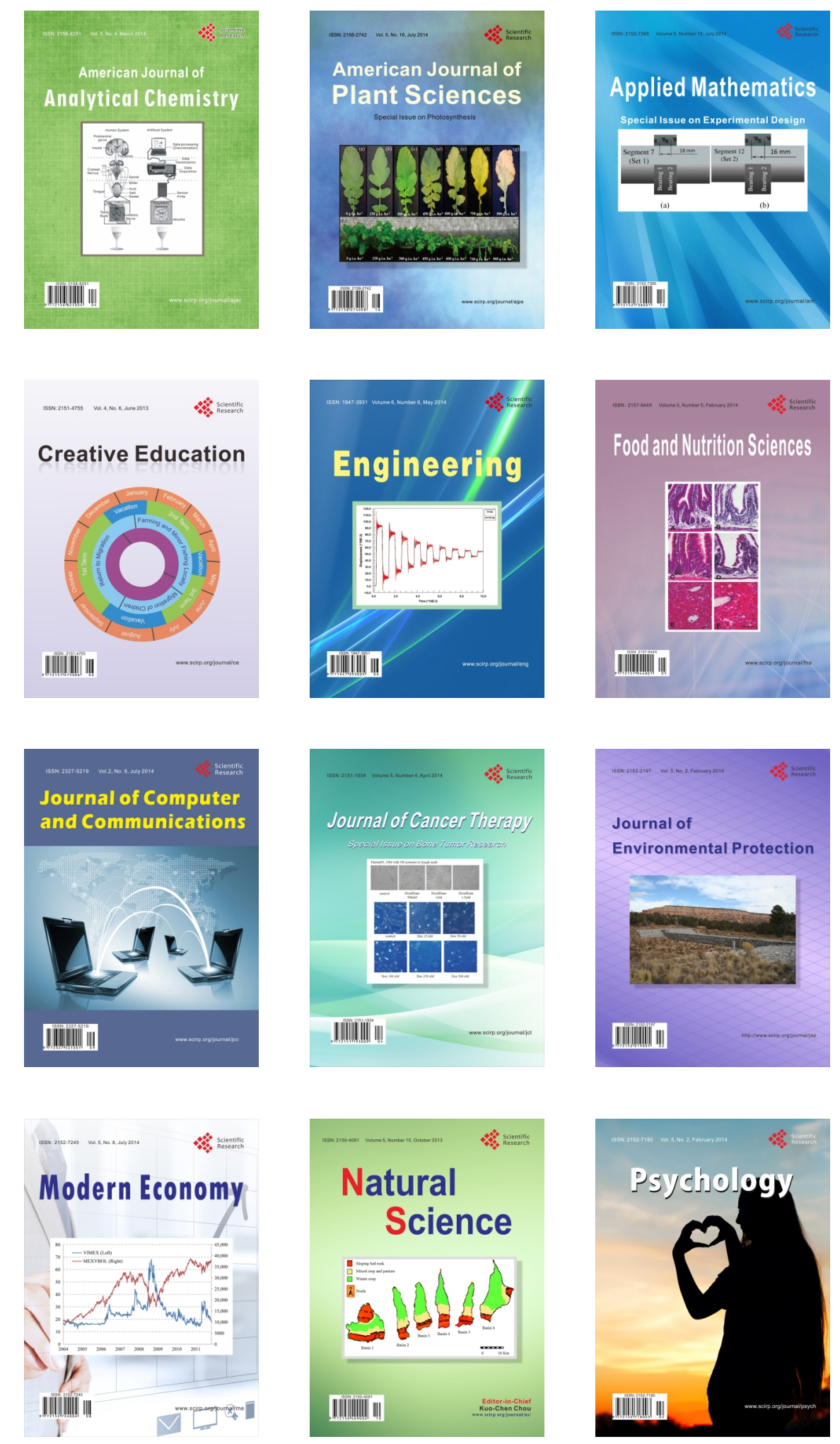